Instructions/Template for Preparing Manuscript for Jendela Nursing Journal

\title{
Literature Review: Relationship of Family Support with the Medication Adherence in Tuberculosis Patients (TB)
}

\author{
Nadya Fickry Martina Suparjo ${ }^{1}$, S. Eko Ch Purnomoํㅜ, Nina Indriyawati ${ }^{1}$ \\ ${ }^{1}$ Nursing Program, Poltekkes kemenkes Semarang, Indonesia \\ Corresponding author: nadyafickry@gmail.com
}

\begin{abstract}
Background: Tuberculosis is an infectious disease caused by the bacterium Mycobacterium tuberculosis. Tuberculosis treatment programs are long and cause some side effects that make patients not adherent to treatment so that family support is needed.
\end{abstract}

Purpose: This study aims to discuss family support with medication adherence in patients with pulmonary tuberculosis.

Methods: The type of research that studies the literature using the PRISMA (Preferred Reporting Items for Systematic Reviews and Meta-analyses) method. This literature study took 17 electronic journals from 112 international and national electronic journals namely pubmed, google scholar, and one search published between 2014 and 2019 with research inclusion criteria, namely articles containing family support and medication adherence in patients with pulmonary tuberculosis.

Results: Most of the literature states that family support is in the good category and has high medication adherence. The most extended family support given to pulmonary tuberculosis patients is informational support and emotional support, while the least support provided is instrumental support. The most dominant adherence factors are the patient's desire to recover or good patient motivation, the role of the family or good family support, and the role of the health worker as a PMO. The relationship of family support with medication adherence in patients with pulmonary tuberculosis showed a significant relationship.

Conclusion: The literature states that the better the family support given to patients with pulmonary tuberculosis, the higher the compliance to take medication for these patients. Family support can improve treatment success in patients with pulmonary TB.

\section{Keywords:}

Tuberculosis, Family Support, Adherence Medication

\section{LATAR BELAKANG}

Tuberkulosis (TB) merupakan penyakit infeksi yang disebabkan oleh bakteri Mycobacterium tuberculosis. Sebagian besar kuman Tuberkulosis menyerang paru tetapi dapat menyerang organ tubuh lainnya. Penyakit Tuberkulosis menyebar dan di 
tularkan melalui udara ketika orang yang terinfeksi tuberkulosis paru batuk, bersin, berbicara atau meludah. (Kementrian Kesehatan Republik Indonesia, 2014).

Penyebaran bakteri Tuberkulosis menduduki peringkat di atas HIV/AIDS. Pada tahun 2016 diperkirakan terdapat 10,4 juta kasus baru tuberkulosis atau 142 kasus/100.000 populasi, dengan 480.000 kasus multidrug-resistant (MDR). Indonesia adalah negara dengan jumlah kasus baru terbanyak kedua di dunia setelah India. Meskipun jumlah kematian akibat tuberkulosis menurun dari 1,7 juta menjadi 1,3 juta antara tahun 2000 dan 2015, tuberkulosis tetap menjadi 9 penyebab dari kematian tertinggi di dunia pada tahun 2016 (World Health Organization, 2018).

Berdasarkan Riskesdas (2018) Prevalensi Tuberkulosis dengan penduduk Jawa Tengah sebesar $(0,36 \%)$ dengan jumlah 132.565 orang. Jumlah kasus tertinggi yang dilaporkan terdapat di provinsi dengan jumlah penduduk yang besar yaitu Jawa Barat sebanyak 78.698 orang, Jawa Timur sebanyak 48.323 orang, dan Jawa Tengah sebanyak 42.272 orang (Kemenkes RI, 2018).

Penyebab tingginya Tuberkulosis Paru adalah penularan bakteri TB terjadi melalui percikan ludan atau saat pasien TB berbicara. Penularan yang cepat inilah yang menjadi pemicu tingginya angka kejadian TB Paru. Selain itu faktor ekonomi dan pendidikan mempengaruhi penyebaran TB Paru. (Kementerian Kesehatan Republik Indonesia 2018, 2018). Strategi penanggulangan tuberkulosis adalah menemukan penderita dan mengobati penderita sampai sembuh dengan strategi Directly Observed Treatment Short Course (DOTS) diterapkan bertahap melalui puskesmas (Rumimpunu, 2018).

Dukungan keluarga diperlukan untuk mendorong pasien Tuberkulosis Paru. Menurut Zahara (2007), dalam penelitiannya menemukan bahwa dukungan keluarga adalah faktor yang penting untuk keberhasilan pasien Tuberkulosis Paru dalam mematuhi program pengobatan. Ketidakpatuhan terhadap pengobatan akan berakibat pada tingginya angka kegagalan dalam pengobatan. Hal ini tentunya akan mempersulit pemberantasan penyakit TB paru di Indonesia serta memperberat beban pemerintah (Pameswari, Halim, \& Yustika, 2016).Penelitian yang dilakukan Gebreweld et al. (2018) menyebutkan bahwa alasan paling umum pasien menghentikan pengobatan adalah "merasa sembuh". Selain itu, jarak antara rumah dengan klinik mempengaruhi pasien dalam melakukan pengobatan secara rutin. Kurangnya dukungan keluarga mempengaruhi kepatuhan pasien dalam pengobatan. Didukung penelitian Pameswari et al. (2016), hasil wawancara ketidakpatuhan pasien tuberculosis disebabkan karena penderita akan merasakan sembuh setelah pengobatan 1-2 bulan, dan terjadinya efek samping kehilangan nafsu makan.

Berdasarkan penelitian yang dilakukan oleh Septia et al. (2014) membuktikan bahwa pasien yang patuh minum obat merupakan hasil dari dukungan keluarga yang baik, yaitu dari 66 pasien yang patuh minum obat sebagian besar adalah yang memiliki dukungan keluarga 74,14\%. Penelitian lain oleh (Maulidia, 2014), menunjukan bahwa dukungan keluarga sangat berpengaruh dalam tingkat kepatuhan berobat penderita. 


\section{TUJUAN}

Tujuan dari penelitian ini adalah untuk mendiskusikan pemanfaatan dukungan keluarga dengan kepatuhan minum obat pada penderita tuberkulosis paru.

\section{METODE}

Desain penelitian yang digunakan kajian literatur dan menggunakan metode PRISMA. Strategi pencarian artikel melalui database jurnal penelitian terindeks nasional dan internasional seperti Pubmed, Google Scholar, One Search, dan sebagainya. Peneliti menentukan jenis artikel penelitian yang digunakan sebagai referensi adalah systematic review, meta-analysis, randomized controlled trial, case control, cohort, kualitatif dan kuantitatif. Kriteria inklusi:artikel penelitian terpubliksasi dan terindeks di jurnal nasional dan internasional periode tahun 2014-2019, jenis artikel penelitian asli, dapat diakses dalam bentuk teks lengkap, dan artikel memuat tentang dukungan keluarga dan kepatuhan minum obat pada penderita tuberkulosis paru. Kriteria eksklusi: yaitu artikel tidak terpublikasi dan artikel yang memuat selain dukungan keluarga dan kepatuhan minum obat pada penderita tuberkulosis paru.

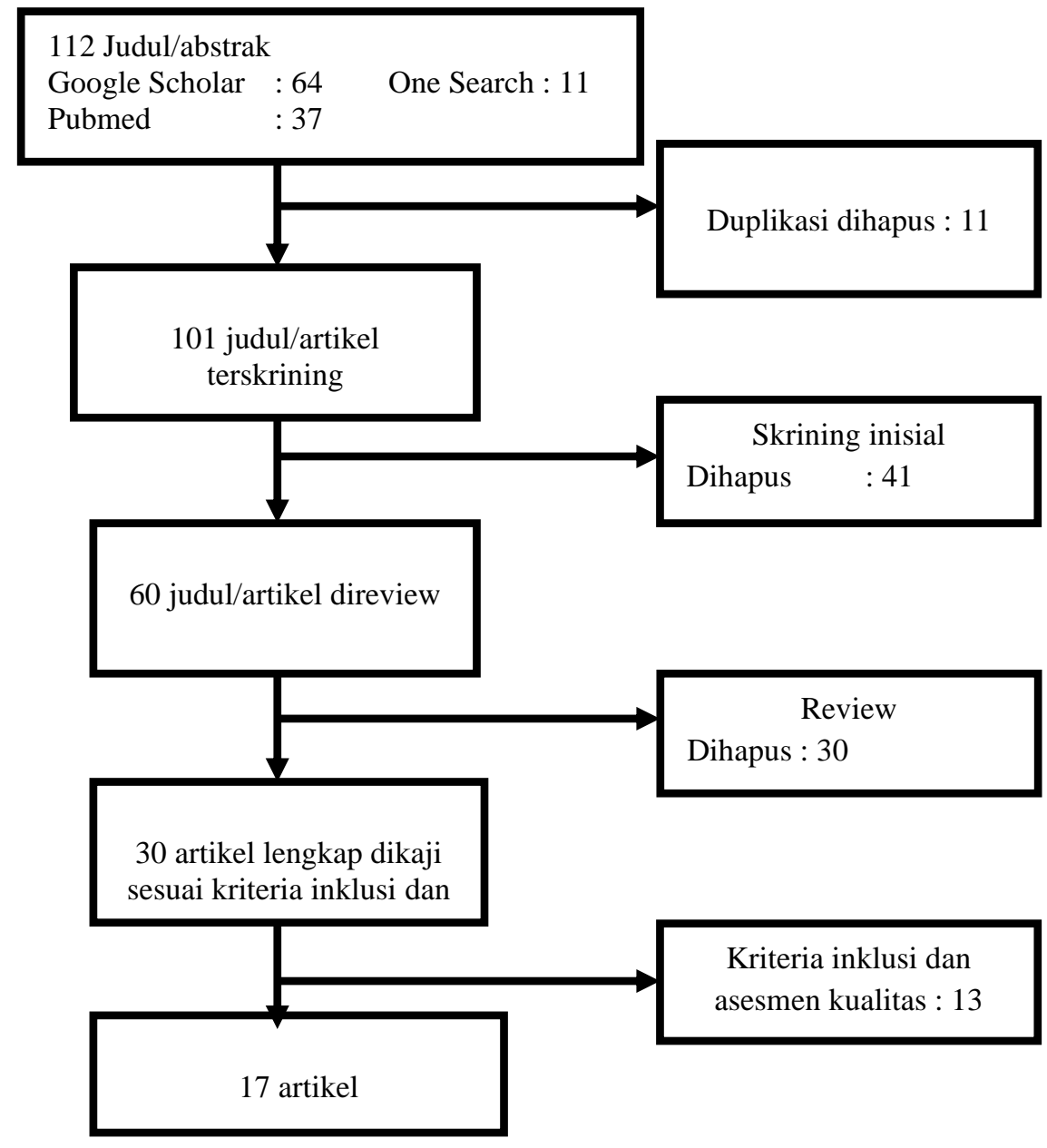

Bagan 1. Proses Seleksi Artikel Penelitian 


\section{HASIL}

Dukungan keluarga merupakan salah satu faktor yang mempengaruhi kepatuhan untuk pengobatan tuberkulosis paru. Faktor lainnya yang mempengaruhi kepatuhan minum obat antara lain faktor predisposisi yaitu demografi (usia, jenis kelamin, pendidikan, pekerjaan), pengetahuan, keyakinan dan nilai sikap, faktor pendukung yaitu efek samping obat, jarak dan faktor pendorong yaitu dukungan keluarga, petugas kesehatan (Notoatmodjo, 2014).

Tabel 1. Ringkasan Artikel Hubungan Dukungan Keluarga Dengan Kepatuhan Minum Obat Pada Penderita Tuberkulosis Paru Tahun 2014-2019 (n=17)

\begin{tabular}{|c|c|c|c|c|c|}
\hline No. & Penulis & Tahun & Desain & Sampel & Hasil \\
\hline 1. & $\begin{array}{l}\text { Maulani } \\
\text { Shaufatus Sara }\end{array}$ & 2017 & $\begin{array}{l}\text { Kuantitat } \\
\text { if dengan } \\
\text { menggun } \\
\text { akan } \\
\text { metode } \\
\text { deskriptif } \\
\text { korelasi } \\
\text { dengan } \\
\text { pendekat } \\
\text { an Cross } \\
\text { Sectional }\end{array}$ & $\begin{array}{l}26 \\
\text { responden }\end{array}$ & $\begin{array}{l}\text { Hasil penelitian menunjukkan bahwa } \\
\text { dukungan keluarga sebagian besar baik } \\
(65.4 \%) \text { dan sebagian besar pasien TB } \\
\text { Paru patuh minum Obat. Hasil uji Chi- } \\
\text { square diperoleh nilai } \mathrm{p}=0,008 \text { dan nilai } \\
\text { contingency coefficient ( } \mathrm{r}=0,506) \text { dan } \\
\text { ada hubungan yang signifikan antara } \\
\text { dukungan keluarga dengan kepatuhan } \\
\text { minum Obat pasien TB Paru di } \\
\text { Puskesmas Umbulharjo I Yogyakarta. }\end{array}$ \\
\hline 2. & $\begin{array}{l}\text { Rieseva Fitria, } \\
\text { Christin Anelina } \\
\text { Febrianti }\end{array}$ & 2016 & $\begin{array}{l}\text { Kuantitat } \\
\text { if dengan } \\
\text { desain } \\
\text { cross } \\
\text { sectional }\end{array}$ & $\begin{array}{l}85 \text { orang } \\
\text { penderita } \\
\text { TB paru }\end{array}$ & $\begin{array}{l}\text { Hasil analisis secara univariat } \\
\text { menunjukkan bahwa }(75,3 \%) \text { responden } \\
\text { patuh minum OAT, }(57,6 \%) \text { responden } \\
\text { mendapat dukungan emosional kategori } \\
\text { tinggi, }(64,7 \%) \text { responden mendapat } \\
\text { dukungan penghargaan kategori tinggi, } \\
(56,5 \%) \text { responden mendapat dukungan } \\
\text { instrumental kategori tinggi, (75,3\%) } \\
\text { responden mendapat dukungan } \\
\text { informasional kategori tinggi. Secara } \\
\text { bivariat menunjukkan ada hubungan } \\
\text { dukungan emosional (p value = 0,004; } \\
\text { OR=5,1), ada dukungan penghargaan (p } \\
\text { value=0,031; OR=3,4), ada dukungan } \\
\text { instrumental (p value = 0,007; OR= } \\
4,7 \text { ), ada dukungan informasional (p } \\
\text { value= 0,001; OR= 16,2) dengan } \\
\text { kepatuhan minum OAT di wilayah kerja } \\
\text { Puskesmas Gading Rejo 2015. }\end{array}$ \\
\hline 3. & Arni Wianti & 2018 & $\begin{array}{l}\text { Deskripti } \\
\mathrm{f} \\
\text { korelatif } \\
\text { dengan } \\
\text { pendekat } \\
\text { an atau }\end{array}$ & $\begin{array}{l}62 \\
\text { responden }\end{array}$ & $\begin{array}{l}\text { Hasil penelitian ini menunjukan bahwa } \\
\text { diketahui } 36,8 \% \text { di Puskesmas } \\
\text { Kaladawa tahun } 2017 \text { tidak patuh } \\
\text { minum obat, } 45,6 \% \text { kurang mendapat } \\
\text { dukungan keluarga sebanyak } 54,4 \% \text {, } \\
\text { Tidak ada hubungan antara dukungan }\end{array}$ \\
\hline
\end{tabular}



desain
cross
sectional

4. Firdaus Rosa

\begin{abstract}
2019
\end{abstract}
Penelitia

n

kuantitati

$\mathrm{f}$ cross

sectional

69

responden

sectional
5. Fadhlie Ibrahim,
Rahma Elliya,
Teguh Pribadi

6. Fitria Yuliana
2014

Kuantitat

if dengan

pendekat

an cross

sectional

Desain

korelasi

dengan

model

Cross

Sectional
42 orang

55

responden
Hasil penelitian menunjukkan identifikasi dukungan keluarga terhadap pengobatan pada pasien tuberculosis paru menunjukkan hasil dukungan keluarga sebesar $85,4 \%$ atau 47 responden dukungan keluarga baik. Hasil identifikasi kepatuhan pengobatan pasien TB Paru menunjukkan hasil $89,1 \%$ patuh dalam pengobatan tuberculosis paru. Hasil analisis hubungan dukungan keluarga dengan kepatuhan pengobatan TB paru berdasarkan hasil pengujian data di atas menunjukkan nilai signifikan $\mathrm{p}$-value $=$ 0,000 berarti Ho ditolak, Ha diterima artinya ada hubungan dukungan keluarga dengan kepatuhan pengobatan $\mathrm{Tb}$ dalam menjalani pengobatan.

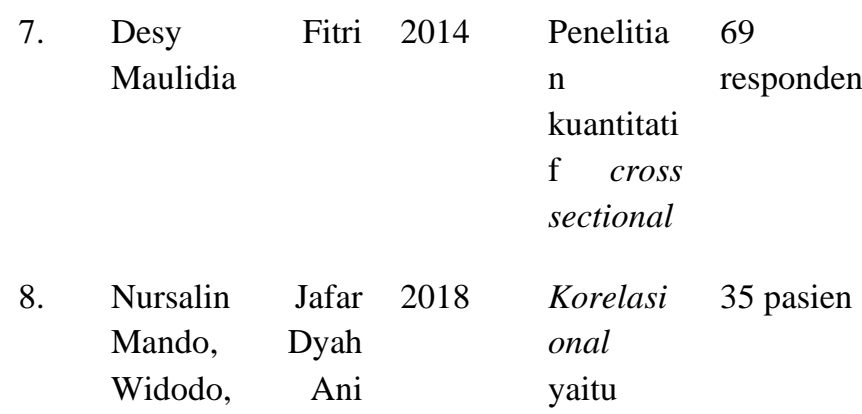

Hasil penelitian menunjukkan bahwa ada hubungan antara dukungan keluarga terhadap kepatuhan minum obat pada penderita TB, dengan hasil $\mathrm{p}$ value setelah uji chi square ialah 0,00.

Hasil uji statistik penelitian sebanyak $65,7 \%$ pasien mendapat dukungan baik dan $91,4 \%$ pasien dikatakan patuh. Hasil 
Sutriningsih

cross

sectional

9. Vieocta Apsari 2014

Paradise

ional
Observas 71 orang

Analitik

dengan

desain

Cross

Sectional

\section{Thirsa Olliva \\ Mongi, Julia \\ Villy Rottie, \\ Anggraene Torar}

2017

Penelitia

$\mathrm{n}$

kuantitati

f cross

sectional
45

responden

analisis bivariat menunjukkan Sig.(2tailed) 0,972 > 0,05. Disimpulkan tidak ada hubungan dukungan keluarga dengan kepatuhan minum obat dengan kekuatan hubungan $r-0,06$.

Berdasarkan uji statistik menggunakan Chi-square Dengan tingkat kepercayaan $95 \%$ dan nilai signifikansi 5\% didapatkan p-value sebesar 0,006. Ratio prevalence ( $\mathrm{Cl} 95 \%$ 1,315-3,234) yang berarti responden dengan dukungan keluarga kategori kurang mempunyai kemungkinan $2 \mathrm{x}$ lebih besar untuk tidak patuh minum Obat dibandingkan dengan responden dengan dukungan keluarga kategori baik. Dari 16 responden yang mendapatkan dukungan keluarga kategori kurang, 12 diantaranya tidak patuh minum Obat.

Hasil penelitian menunjukkan bahwa persentase responden yang memiliki dukungan baik sebesar 64,4\%, dukungan buruk sebesar 35,6\%. Persentase responden yang patuh $44,4 \%$, dan tidak patuh $55,6 \%$. Hasil uji Chi Square didapatkan nilai $\mathrm{p}$ value $=0,00$ yakni lebih kecil dari 0,05. Hitungan statistik bermakna atau ada hubungan antara variabel dukungan keluarga terhadap variabel kepatuhan minum obat.

11. Asra Septia, Siti 2014 Survey 58 orang

Rahmalia,

Febriana Sabrian

analitik

dengan

rancanga

n survey

cross

sectional

12. Nita Rachman 2016 Deskripti 35

Dwi Nur Afriani f penderita

korelasio

nal

dengan

pendekat

an cross

sectional

Hasil uji statistik nilai $\mathrm{p}$-value $=0.036$ $(\mathrm{p}<0,05)$. Berdasarkan hipotesis yang diajukan apabila $\mathrm{p}$-value $\leq=0.05$ maka dapat dikatakan ada hubungan yang bermakna antara dua variabel, sehingga Ho ditolak.

Hasil identifikasi menunjukkan hasil dukungan keluarga sebesar $82,9 \%$ atau 29 responden dukungan keluarga baik. Hasil identifikasi kepatuhan pengobatan pasien TB paru menunjukkan hasil $88,6 \%$ patuh dalam pengobatan tuberculosis paru. Hasil analisis hubungan dukungan keluarga dengan kepatuhan pengobatan TB paru 
13. Safira Nur 2019

Ainiyah,

Soedarsono,

Pirlina Umiastuti

14. Alfid Tri Afandi

Observas
ional
Analitik
dengan
desain
Cross

Cross

Sectional

Literatur
e review

situs

pencari

google,

Perpustaka

an

Nasional

Republik

Indonesia

(PNRI),

master

jurnal,

diterbitkan

antara

tahun

2006-2016

15. Minlan Xu, 2017

Urban

Markström,

Juncheng Lyu,

Lingzhong $\mathrm{Xu}$

16. Shahab E Saqib, 2019

Mokbul Morshed

Cross

Sectional

Ahmad,

Sanaullah

Panezai $\begin{array}{ll}\text { Cross } & 358 \text { pasien } \\ \text { Sectional } & \text { TB }\end{array}$

269 pasien berdasarkan hasil pengujian data diatas menunjukkan nilai signifikasi $\mathrm{p}$-value $=$ 0,000 berarti Ho ditolak, Ha diterima artinya ada hubungan dukungan keluarga dengan kepatuhan pengobatan tuberkulosis paru dalam menjalani pengobatan.

Pada penelitian ini menunjukkan adanya hubungan yang signifikan antara dukungan penilaian keluarga dan kepatuhan pasien TB-MDR terhadap pengobatan.

358 pasien Hasil penelitian menujukkan bahwa faktor-faktor yang terkait dengan kepatuhan rendah yaitu usia yang lebih tua, pengobatan yang lama (tiga bulan atau lebih) dan depresi.

Hasil penelitian menunjukkan bahwa faktor-faktor seperti usia pasien, jenis kelamin, status perkawinan, ukuran rumah tangga, pendapatan bulanan, dan kepemilikan rumah diidentifikasi sebagai faktor signifikan yang terkait dengan dukungan sosial yang diterima oleh pasien. Tidak ada perbedaan yang signifikan dalam pekerjaan rumah tangga utama.

17. Frezghi Hidray 2018 Studi 39 pasien Hasil penelitian menyatakan bahwa 


Gebreweld,
Meron Mehari
Kifle, Fitusm
Eyob
Gebremicheal,
Leban Lebahati
Simel, Meron
Mebrahtu Gezae,
Shewit Sibhatu
Ghebreyesus,
Yordanos
Tesfamariam
Mengsteab,
Nebiat Ghirmay
Wahd

Kualitatif TB

kurangnya pengetahuan, kehilangan pekerjaan dan penghasilan, adanya stigma dari masyarakat, kurangan dukungan sosial, efek samping obat, dan durasi pengobatan yang lama merupakan hambatan untuk kepatuhan pengobatan. Sedangkan jarak ke fasilitas Kesehatan yang terjangkau dan komunikasi serta penerimaan yang baik dari petugas kesehatan merupakan faktor yang memungkinkan kepatuhan pada pengobatan.

Setelah menganalisis artikel penelitian, peneliti mendapatkan data bahwa karakteristik pasien berdasarkan usia yang menjalani pengobatan tuberkulosis terbanyak yaitu pada usia > 50 tahun, kemudian pada usia 20 hingga 30 tahun dan pada usia 26 hingga 45 tahun. Sesuai dengan data pada artikel penelitian Xu, Markström, Lyu, \& Xu (2017) dari 358 responden dan usia rata-rata pasien adalah 54 tahun. Penelitian yang dilakukan Gebreweld et al. (2018) sebanyak 14 responden berada pada usia 20-30 tahun. Penelitian oleh Rosa (2019) usia yang mendominasi terdapat pada usia 26-45 tahun.

Berdasarkan 17 kajian literatur penelitian yang telah dianalisis didapatkan bahwa terdapat hubungan antara dukungan keluarga dengan kepatuhan minum obat pada penderita tuberkulosis paru. Hasil penelitian Rosa (2019) menunjukan bahwa ada hubungan antara dukungan keluarga terhadap kepatuhan minum obat pada penderita tuberkulosis paru, dengan hasil $p$ value setelah uji chi square ialah 0,00 . Hasil penelitian ini sejalan dengan penelitian yang dilakukan oleh Sara (2017) yang menunjukkan hasil chi-square diperoleh nilai $\mathrm{p}=0,008$ yang berarti $\mathrm{p}<0,05$ menunjukkan bahwa ada hubungan antara dukungan keluarga terhadap kepatuhan minum obat pasien TB paru. Demikian pula dengan penelitian yang dilakukan oleh Septia et al. (2014) menunjukkan bahwa hasil uji statistik chi-square dengan tingkat kemaknaan $(\alpha)=5 \%$ dan tingkat kepercayaan $95 \%$ didapatkan nilai p-value $=0,036$. Nilai p-value ini lebih kecil dari $(\alpha)$ $=0,05$ menunjukkan bahwa ada hubungan bermakna antara dukungan keluarga dengan kepatuhan minum obat.

\section{PEMBAHASAN}

Dukungan keluarga merupakan sikap dan tindakan penerimaan keluarga terhadap anggota keluarganya, berupa dukungan penilaian, dukungan informasional, dukungan emosional, dan dukungan instrumental (Friedman, 2010). Berdasarkan kajian artikel dari 17 artikel penelitian yang dilakukan menunjukkan bahwa dukungan keluarga dapat meningkatkan keberhasilan pengobatan pada penderita tuberkulosis paru. Hal ini sesuai dengan penelitian Mongi et al. (2017) menyatakan bahwa dukungan keluarga mempunyai peran yang sangat penting bagi kesembuhan pasien tuberkulosis. Dimana keluarga selalu mengingatkan agar berobat sampai tuntas, selalu mengingatkan untuk minum obat tepat waktu dan selalu mendampingi pasien saat kontrol dan selalu 
memperhatikan pasien saat sakit. Didukung juga oleh penelitian Septia et al. (2014) menyatakan bahwa dukungan keluarga sangat menunjang keberhasilan pengobatan dengan cara selalu mengingatkan pasien minum obat, pengertian pada pasien dan memberi semangat agar tetap rajin berobat. Hal ini sesuai dengan teori yang dikemukakan oleh Friedman (2013) bahwa orang yang hidup dalam lingkungan yang bersifat suportif, kondisinya jauh lebih baik dari pada mereka yang tidak memiliki lingkungan suportif. Dalam hal ini, penting sekali bagi pasien tuberkulosis paru untuk berada dalam lingkungan keluarga yang mendukung kesehatannya, sehingga pasien TB Paru akan selalu terpantau kesehatannya.

Berdasarkan hasil penelitian Mando, Widodo, \& Sutriningsih (2018) bahwa dukungan keluarga yang didapatkan oleh pasien TB Paru sebagian besar mendapatkan dukungan yang baik. Dukungan yang baik ini salah satunya disebabkan oleh faktor tahap perkembangan. Hal ini selaras dengan teori yang dikemukakan oleh Purnawan (2008) bahwa setiap rentang usia memiliki pemahaman dan respon yang berbeda-beda terhadap perubahan kesehatan.

Bentuk dukungan keluarga ada empat yaitu yang pertama adalah dukungan emosional. Dalam dukungan emosional, keluarga sebagai sebuah tempat yang aman dan damai untuk istirahat dan pemulihan serta membantu penguasaaan terhadap emosi (Friedman, 2010). Dukungan emosional terhadap pasien sangat dibutuhkan karena dukungan ini dapat meningkatkan harga diri pasien tuberkulosis paru karena biasanya merasa malu dengan penyakitnya. Keluarga merupakan sistem pendukung utama yang membantu dalam perawatan secara langsung pada keadaan sehat maupun sakit. Ketika pasien menjalani pengobatan tuberkulosis paru banyak hal yang membuat pasien merasa down. Hal ini karena hilangnya kepercayaan diri dari diri pasien tuberkulosis paru dengan penyakit yang dideritanya. Berdasarkan penelitian yang dilakukan oleh Saqib et al. (2019) Pasien yang memiliki >15 anggota keluarga menerima dukungan sosial yang lebih tinggi yaitu sebesar $71,78 \%$. Hal ini berarti dukungan keluarga memberikan peranan penting dalam menentukan kondisi pasien. Maka dari itu dengan adanya dukungan dari keluarga pasien merasa memperoleh social support. Sehingga pasien tuberkulosis mendapat dukungan emosional yang baik.

Dukungan keluarga yang kedua adalah dukungan informasional. Dukungan informasi ini bisa berupa pemberian nasehat, saran, usulan, petunjuk dan pemberian informasi kepada pasien tentang pengobatan yang sedang dijalaninya. Hal ini sesuai dengan penelitian Paradise (2014) yang menyatakan bahwa responden mendapatkan dukungan informasional yang baik yaitu memberikan informasi tentang hasil pemeriksaan dan pengobatan, mengingatkan pasien untuk minum obat, serta keluarga dapat menjelaskan setiap kali pasien bertanya tentang OAT. Dukungan informasi semakin tinggi apabila informasi yang diberikan pada pasien dimengerti dan diikuti oleh pasien. Didalam dukungan informasi ini komunikasi tidak hanya antara keluarga dan pasien tuberkulosis saja tetapi petugas kesehatan pun dibutuhkan karena untuk memberikan informasi seperti informasi tentang penyakit $\mathrm{TB}$, dan dapat memberikan konsultasi kepada pasien TB, banyaknya informasi dan banyaknya konsultasi kepada pasien, hal ini bisa membuat pasien tuberkulosis paham dan mengerti akan penyakit yang dideritanya sehingga termotivasi untuk pengobatan sampai sembuh. 
Dukungan keluarga yang ketiga adalah dukungan instrumental. Dukungan instrumental yang diberikan keluarga kepada pasien bisa berupa dana, pemberian pertolongan, pengawasan ketat, dan lain sebagainya. Penelitian oleh Paradise (2014) dalam penelitian ini keluarga selalu menyediakan dana yang dibutuhkan saat proses pengobatan dan menyiapkan obat saat akan diminum. Sesuai dengan teori friedman dalam Setiadi (2008) Bantuan bentuk ini bertujuan untuk mempermudah seseorang dalam melakukan aktifitasnya berkaitan dengan persoalan-persoalan yang dihadapinya, atau menolong secara langsung kesulitan yang dihadapi misalnya dengan memberikan kebutuhan yang dibutuhkan pasien seperti membelikan makanan dan minuman yang bergizi untuk mencukupi kebutuhan nutrisi pasien tuberkulosis paru. Dukungan Instrumental sangat diperlukan pada pasien tuberkulosis karena dengan terpenuhinya segala kebutuhan jasmani dan rohani hal ini dapat meningkatkan harga diri pasien.

Dukungan keluarga yang keempat adalah dukungan penghargaan atau penilaian. Dukungan penghargaan yang diberikan kepada pasien tuberkulosis paru berfokus pada aspek positif berupa pujian atas kemajuan kesehatan dan selalu mencintai serta memperhatikan keadaan pasien selama sakit dan menerima penderita apa adanya. Dukungan penilaian atau dukungan penghargaan bertujuan untuk membangun harga diri pasien, memberikan semangat, dukungan, motivasi agar pasien bisa pulih dan tidak menyerah (Ainiyah et al., 2019).

Berdasarkan kajian literatur terhadap 17 artikel penelitian didapatkan bahwa dari keempat dukungan keluarga yaitu dukungan emosional, dukungan informasi, dukungan instrumental dan dukungan penghargaan yang paling banyak diberikan kepada pasien tuberkulosis paru yaitu dukungan informasional dan dukungan emosional, sedangkan dukungan yang paling kurang diberikan yaitu dukungan instrumental. Hal ini terjadi karena dukungan informasional merupakan dukungan yang paling mudah diberikan dibandingkan dengan dukungan yang lain. Rendahnya dukungan instrumental dikarenakan mayoritas keluarga pasien tuberkulosis paru berada pada status ekonomi yang rendah.

Berdasarkan beberapa penelitian yang telah dianalisis menunjukkan bahwa sebagian besar responden yang patuh dalam pengobatan masih tinggi. Kepatuhan minum obat juga secara tidak langsung dapat meningkatkan kualitas hidup penderita dengan tuberkulosis paru, tanpa mengesampingkan tugas dari petugas kesehatan yang menjadi pengawas minum obat (PMO) (Afandi, 2016). Hal ini sejalan dengan teori Notoatmodjo (2014) menyatakan tindakan individu untuk melakukan pengobatan dan pencegahan penyakit akan didorong pula oleh keseriusan penyakit tersebut terhadap individu atau masyarakat.

Berbeda dengan penelitian Mongi et al. (2017) bahwa sebagian besar responden tidak patuh dalam pengobatan. Hal ini dikarenakan kurangnya pengetahuan dari responden akan pentingnya minum obat secara teratur. Didukung dengan sedikitnya responden yang berpendidikan tinggi. Perbedaan tingkat pendidikan juga mempengaruhi dalam proses pengobatan karena beberapa responden ada yang tidak bisa menerima informasi dengan langsung dan memiliki pemahaman yang berbeda-beda sehingga dapat menyebabkan ketidaksesuaian dalam pencapaian (Afandi, 2016). 
Sesuai dengan teori Modifikasi Lawrence Green dalam Notoatmodjo (2014) bahwa faktor yang berhubungan dengan perilaku kepatuhan berobat yaitu predisposing factors, enabling factors, dan reinforcing factors yang diantaranya pengetahuan, keyakinan, nilai sikap, demografi (usia, jenis kelamin, pendidikan, pekerjaan, penghasilan, lama pengobatan), efek samping obat, jarak, dukungan keluarga, dan petugas kesehatan.

Pada kajian literatur, usia yang mendominasi pada penderita tuberkulosis adalah usia $>50$ tahun, kemudian pada rentang usia 20-30 tahun dan pada usia 26-45 tahun. Berdasarkan hasil penelitian ini, peneliti menganalisis bahwa kasus terbanyak berada pada usia produktif. Usia produktif merupakan usia yang aktif beraktivitas diluar lingkungan rumah sehingga lebih beresiko mudah menularnya penyakit tuberkulosis paru terutama di lingkungan yang padat. Penelitian Maulidia (2014) menyatakan bahwa mayoritas umur yang rentan terkena penyakit tuberkulosis yaitu pada usia pertengahan karena seseorang akan cenderung lebih aktif berinteraksi sosial dan mempunyai mobilitas yang tinggi sehingga kemungkinan untuk terpapar kuman tuberkulosis lebih besar.

Pada orang lansia akan mempunyai kesulitan dalam pengobatan dan memiliki kepatuhan yang lebih rendah karena seseorang yang berusia lanjut sering lupa minum obat (Xu et al., 2017). Para lansia dianggap membutuhkan lebih banyak perhatian dari keluarga, teman dan komunitas. Karena itu, lansia memiliki dukungan sosial yang lebih tinggi (Saqib et al., 2019).

Berdasarkan hasil penelitian karakteristik responden berdasarkan jenis kelamin yang paling mendominasi adalah laki-laki. Penelitian yang dilakukan oleh (Sara, 2017) karakteristik jenis kelamin laki-laki ini lebih tinggi karena laki-laki sebagian besar mempunyai kebiasaan merokok sebab kebiasaan merokok meningkatkan risiko untuk terkena TB paru.

Berdasarkan kajian literatur didapatkan bahwa pendidikan terakhir yang paling mendominasi adalah SMA. Penelitian yang dilakukan Afriani (2016) menunjukkan bahwa semakin rendah tingkat pendidikan yang dimiliki maka akan semakin rendah pula kemampuan yang akan dimiliki oleh seseorang dalam menyikapi suatu permasalahan. Pasien tuberkulosis yang memiliki latar belakang pendidikan yang kurang maka akan mengalami kesulitan untuk menerima informasi baru dan sulit menyerap informasi tentang pengobatan TB Paru. Tingkat pendidikan pasien akan sangat berpengaruh pada pengetahuannya terhadap penularan penyakit tuberkulosis paru di masyarakat.

Berdasarkan penelitian didapatkan rata-rata pekerjaan pasien tuberkulosis paru adalah sebagai wiraswasta dan buruh tani. Pekerjaan akan mempengaruhi kepatuhan pengobatan pasien tuberkulosis paru. Sesuai dengan penelitian Rosa (2019) dalam penelitiannya didapatkan data bahwa sebanyak 44\% adalah yang bekerja sebagai wiraswasta. Pasien yang bekerja sebagai wiraswasta akan lebih sering berada di luar ruangan dengan kondisi lingkungan yang mudah terpapar polusi udara dan biasanya pasien tuberkulosis paru tidak patuh menggunakan masker. Pasien juga biasanya kurang waktu istirahat dan pola hidup yang tidak sehat sehingga akhirnya mengganggu kesehatan serta mudah mengalami penyakit tuberkulosis paru. 
Berdasarkan beberapa penelitian yang telah dianalisis bahwa penghasilan pasien ratarata rendah. Hasil penelitian ini didukung oleh Xu et al. (2017) menunjukkan bahwa penghasilan yang didapat dibawah rata-rata $68,72 \%$. Penghasilan tersebut biasanya dipengaruhi oleh pekerjaan yang tidak menetap, pekerjaan dengan penghasilan berjumlah sedikit, dan berada pada sosial ekonomi yang rendah.

Faktor pengetahuan juga berpengaruh terhadap kepatuhan pengobatan tuberkulosis paru. Berdasarkan beberapa hasil penelitian yang telah dianalisis menunjukkan bahwa tingkat pendidikan yang paling dominan pada pasien tuberkulosis adalah SMA, tidak menutup kemungkinan pengetahuan yang dimiliki pasien tuberkulosis paru akan menjadi baik karena tamatan SMA biasanya memiliki daya serap dengan pengetahuan yang cukup baik dan dapat mempengaruhi keputusan pasien dalam mematuhi pengobatan tuberkulosis paru.

Berdasarkan penelitian faktor terkait kepatuhan pengobatan tuberkulosis paru adalah keyakinan dan motivasi pasien. Keyakinan pasien untuk sembuh bisa mendorong pasien melakukan pengobatan secara teratur. Apabila pasien percaya, yakin dan sadar akan sembuh bila berobat secara teratur maka akan tercapai keberhasilan pengobatan tuberkulosis paru. Motivasi pasien yang baik juga dipengaruhi oleh orang terdekat pasien yaitu keluarga. Peran keluarga merupakan motivasi terbesar untuk diri pasien. Pasien akan lebih rajin meminum dan mengambil obat tuberkulosis paru berdasarkan jadwal tertulis yang sudah ditentukan oleh petugas kesehatan pada kartu jadwal kunjungan berobat.

Faktor terkait kepatuhan pada pasien tuberkulosis selanjutnya yaitu sikap pasien terhadap pengobatan. Dimana apabila pasien merasakan efek samping yang akan muncul setelah minum OAT, maka cara pasien dalam mengatasi efek samping obat tersebut adalah dengan melaporkan keluhan tersebut kepada petugas kesehatan. Apabila petugas kesehatan mampu mengatasi keluhan pasien terhadap pengobatan tuberkulosis paru, maka sikap petugas tersebut mampu mengubah sikap pasien menjadi tidak putus berobat selama masa pengobatan tuberkulosis paru sampai selesai.

Faktor efek samping juga berpengaruh terhadap kepatuhan minum obat tuberkulosis paru. Penelitian Gebreweld et al. (2018) menunjukkan bahwa beberapa pasien tuberkulosis paru mengeluhkan tentang efek samping setelah minum OAT. Beberapa dari pasien percaya bahwa pengobatannya memperburuk kondisi mereka. Maka dari itu petugas kesehatan wajib memberikan informasi terkait efek samping yang akan terjadi.

Meskipun dari beberapa pasien tuberkulosis paru telah minum OAT lebih dari 2 bulan, namun masih ada sebagian pasien yang tetep merasakan efek samping tersebut. Inilah yang cukup berpengaruh terhadap kepatuhan pasien untuk minum obat, karena pasien akan merasa trauma dengan efek samping yang timbul setelah minum obat. Selain itu pasien merasa kurang nyaman karena terkadang efek samping tersebut juga dapat mengganggu aktivitas mereka. Mengingat aktivitas sebagian besar pasien adalah sebagai petani, maka dengan terganggunya aktivitas ini juga akan berpengaruh terhadap penghasilan. Dan pasien biasanya baru akan mengunjungi fasilitas pelayanan kesehatan jika efek samping yang dirasakan tersebut semakin parah. 
Berdasakan penelitian yang telah dianalisis faktor lainnya terkait kepatuhan adalah akses dari rumah menuju ke pelayanan kesehatan meliputi jarak, biaya perjalanan, lamanya perjalanan, jenis transportasi, dan hambatan lain yang menghalangi pasien tuberkulosis mendapatkan layanan kesehatan. Penelitian yang dilakukan oleh Gebreweld et al. (2018) menunjukkan bahwa jarak yang jauh dari rumah menuju pelayanan kesehatan, biaya transportasi yang mahal dan tidak tersedianya transportasi menuju tempat berobat serta lamanya mencapai fasilitas kesehatan dapat menjadi hambatan untuk kepatuhan pengobatan.

Faktor lainnya terkait kepatuhan pengobatan pada pasien tuberkulosis paru adalah peran keluarga. Berdasarkan hasil penelitian didapatkan bahwa dukungan keluarga dikategorikan baik. Dengan adanya bantuan yang diberikan oleh anggota keluarga terhadap pasien berupa barang, jasa, informasi, dan nasehat dapat berdampak pada kondisi pasien yang jauh lebih baik daripada mereka yang tidak memiliki dukungan positif dari keluarga pasien. Dukungan keluarga dari orang yang paling dekat dengan penderita sangat dibutuhkan sebagai tempat mendapatkan semangat, kasih sayang dan pengertian (Afriani, 2016)

Kurangnya kepatuhan minum obat disebabkan oleh kurangnya dukungan keluarga (Wianti, 2017). Dengan adanya dukungan keluarga dan motivasi penuh dari keluarga maka akan mempengaruhi perilaku minum obat secara teratur. Selain itu dukungan dari teman sesama penderita atau peer group support dapat membantu dalam proses pengobatan agar pengobatan lebih optimal dan nantinya akan meningkatkan harapan hidup atau kualitas hidup pasien (Afandi, 2016).

Faktor terakhir terkait kepatuhan minum obat yaitu peran petugas kesehatan terkait PMO. Peran petugas kesehatan merupakan faktor eksternal yang ada di lingkungan pasien tuberkulosis paru yang akan berpengaruh terhadap kepatuhan pengobatan. Peran petugas kesehatan ini yaitu rajin memberi tahu cara minum obat kepada pasien tuberkulosis paru, menjelaskan efek samping obat, rajin menasehati pasien tuberkulosis paru mengenai jadwal pengobatan, mengingatkan agar tidak berhenti minum obat paru karena bisa resisten dan diulang kembali pengobatannya dari awal.

Menurut teori Niven (2012) kualitas interaksi antara petugas kesehatan dan pasien merupakan bagian yang penting dalam menentukan derajat kepatuhan. Tak seorang pun dapat mematuhi intruksi jika salah paham tentang intruksi yang diberikan kepadanya. Namun kadang-kadang hal ini bisa juga disebabkan oleh kegagalan petugas kesehatan dalam memberikan informasi yang lengkap, penggunaan istilah medis dan memberikan banyak intruksi yang harus diingat oleh pasien. Dukungan dari petugas kesehatan merupakan faktor lain yang dapat mempengaruhi perilaku kepatuhan.

Berdasarkan hasil penelitian yang telah dianalisis mayoritas pasien tuberkulosis paru memiliki kepatuhan pengobatan yang tinggi dipengaruhi oleh keinginan pasien untuk sembuh atau motivasi pasien yang baik, peran keluarga atau dukungan keluarga yang baik, dan peran petugas kesehatan sebagai PMO dan keluarga akan mampu mengubah pola pikir pasien untuk patuh dalam semua prosedur pengobatan tuberkulosis paru sehingga pasien sembuh. Pasien juga mengetahui bahwa apabila tidak patuh dalam pengobatan tuberkulosis dan meminum obat TB dengan rutin, maka pasien akan 
beresiko untuk mengulang kembali pengobatan tuberkulosis parunya dan mengetahui tentang penyakit TB paru. Faktor-faktor tersebut dapat mempengaruhi pasien agar semangat dan patuh dalam pengobatan tuberkulosis paru secara teratur.

Berdasarkan kajian literatur dari 16 artikel penelitian didapatkan ada hubungan antara dukungan keluarga dengan kepatuhan minum obat pada penderita tuberkulosis paru. Penderita dengan dukungan keluarga yang baik sebagian besar patuh dalam pengobatan. Didapatkan bahwa apabila semakin tinggi dukungan keluarga yang didapatkan maka semakin meningkat kepatuhan minum obat.

Penelitian Afriani (2016), Yuliana (2019), Fitria \& Febrianti (2016), Ibrahim et al. (2014), Paradise (2014), Maulidia (2014), Mongi et al. (2017), Rosa (2019), Maulani Shaufatus (2017), Septia et al. (2014) menunjukkan ada hubungan dukungan keluarga dengan kepatuhan minum obat pada penderita tuberkulosis paru. Kepatuhan dalam pengobatan akan meningkat apabila pasien mendapatkan bantuan dari keluarganya sendiri. Dukungan keluarga mempunyai peran yang sangat penting bagi kepatuhan pasien TB paru. Selain sebagai pihak yang selalu mendukung untuk kesembuhan keluarga juga bertanggung jawab sebagai Pengawas Minum Obat (PMO) yang nantinya akan berperan untuk mengawasi dan mengingatkan secara terus menerus kepada pasien agar pasien meminum obatnya secara teratur dan tepat waktu sesuai dengan dosis yang sudah ditetapkan oleh petugas kesehatan.

Penelitian Afriani (2016) menunjukkan bahwa adanya dukungan keluarga terhadap pasien dapat memberikan ketenangan pada pasien. Selain itu dengan adanya dukungan keluarga dapat berdampak pada kemudahan pasien tuberkulosis paru dalam menjalani pengobatan. Hal ini sejalan dengan penelitian Fitria \& Febrianti (2016) menyatakan bahwa dukungan keluarga dibutuhkan karena keluarga bisa menjadi motivator kuat bagi pasien apabila selalu mendampingi pasien dan mengingatkan pasien jika lupa jadwal kontrol. Sesuai dengan teori Niven (2012) bahwa keluarga dapat menjadi faktor yang sangat berpengaruh dalam menentukan keyakinan dan nilai kesehatan individu serta dapat juga menentukan tentang program pengobatan yang dapat mereka terima.

Namun tidak sejalan dengan hasil penelitian Wianti (2017) menyebutkan bahwa tidak ada hubungan antara dukungan keluarga dengan kepatuhan minum obat pada penderita tuberkulosis paru. Tidak adanya hubungan, hal ini dapat dimungkinkan selain dukungan keluarga juga ada faktor lain seperti efek obat atau lainnya yang dapat juga mempengaruhi ketidakpatuhan pasien. Menurut teori Modifikasi Lawrence Green dalam Notoatmodjo (2014) adanya efek samping obat bisa menjadi penyebab terjadinya kegagalan dalam pengobatan. Hal ini bisa diatasi dengan adanya penyuluhan pada penderita, sehingga penderita akan mengetahui terlebih dahulu tentang efek samping obat.

Penelitian lainnya juga menunjukkan hasil yang sama dimana tidak ada hubungan antara dukungan keluarga dengan kepatuhan minum obat pada penderita tuberkulosis paru (Mando et al., 2018). Kemungkinan besar disebabkan oleh faktor lain yang tidak masuk dalam penelitian ini. Salah satunya adalah faktor petugas kesehatan yang memberikan pelayanan sangat baik yaitu ramah dengan pasien dan bahasa yang digunakan mudah dimengerti oleh pasien. Ataupun faktor lain yaitu jarak tempat tinggal 
dan transportasi yang dijangkau oleh pasien. Hal ini sesuai dengan teori Niven (2012) bahwa kepatuhan pasien akan dipengaruhi oleh sikap dan cara petugas kesehatan dalam melayani pasiennya dan akomodasi yaitu jarak antara tempat tinggal dengan tempat pelayanan kesehatan.

\section{SIMPULAN}

Faktor yang berhubungan dengan perilaku kepatuhan berobat adalah predisposing factors, enabling factors, dan reinforcing factors yang diantaranya pengetahuan, keyakinan, nilai sikap, demografi (usia, jenis kelamin, pendidikan, pekerjaan, penghasilan, lama pengobatan), efek samping obat, jarak, dukungan keluarga, dan petugas kesehatan. Diantara faktor tersebut yang paling dominan adalah keinginan pasien untuk sembuh atau motivasi pasien yang baik, peran keluarga atau dukungan keluarga yang baik, dan peran petugas kesehatan sebagai PMO dan keluarga. Faktor tersebut akan berpengaruh dan mampu mengubah pola pikir pasien untuk patuh dalam semua prosedur pengobatan tuberkulosis paru sehingga pasien dapat sembuh. Dukungan keluarga dengan kepatuhan minum obat pada penderita tuberkulosis paru juga memiliki hubungan yang signifikan. Semakin baik dukungan keluarga yang diberikan kepada penderita tuberkulosis paru, maka semakin tinggi kepatuhan minum obat pada penderita tersebut. Dukungan dari keluarga yang diberikan pada pasien tuberkulosis paru akan sangat berpengaruh dalam kepatuhan minum obat karena dengan perhatian yang lebih dari keluarga maka pasien merasa tidak sendiri dalam menghadapi pengobatan.

\section{REFERENSI}

Afandi, A. T. (2016). Studi Literatur: Efektifitas Peer Group Support Terhadap Kualitas Hidup Klien Tuberkulosis Paru Dan Penyakit Kronik.

Afriani, N. R. D. N. (2016). Hubungan Dukungan Keluarga Dengan Kepatuhan Pengobatan Tuberculosis Paru Di Rumah Sakit Paru Manguharjo Kota Madiun. 41.

Ainiyah, S. N., Soedarsono, S., \& Umiastuti, P. (2019). The Relationship between Family's Assessment Support and MDR TB Patient's Adherence on Treatment in RSUD Dr. Soetomo Surabaya. JUXTA: Jurnal Ilmiah Mahasiswa Kedokteran Universitas Airlangga, 10(2), 75. https://doi.org/10.20473/juxta.v10i22019.75-78

Fitria, R., \& Febrianti, C. A. (2016). Hubungan Dukungan Keluarga Dengan Kepatuhan Minum Obat pada Pasien Tuberkulosis Paru di Wilayah Kerja Puskesmas Gading Rejo 2015. Jurnal Dunia Kesmas, 5, 24-31.

Friedman. (2013). Keperawatan Keluarga. Yogyakarta: Gosyen Publishing.

Friedman, M. M. (2010). Buku Ajar Keperawatan Keluarga: Riset, Teori, dan Praktek. Jakarta: EGC.

Gebreweld, F. H., Kifle, M. M., Gebremicheal, F. E., Simel, L. L., Gezae, M. M., Ghebreyesus, S. S., ... Wahd, N. G. (2018). Factors influencing adherence to tuberculosis treatment in Asmara, Eritrea: a qualitative study. Journal of Health, Population, and Nutrition, 37(1), 1. https://doi.org/10.1186/s41043-017-0132-y

Ibrahim, F., Elliya, R., \& Pribadi, T. (2014). Hubungan Dukungan Keluarga Dengan Kepatuhan Minum Obat TB Paru Pada Penderita TB Paru Di Wilayah Kerja Puskesmas Panaragan Jaya Kabupaten Tulang Bawang Barat Tahun 2013. Jurnal Kesehatan Holistik, 8(2), 71-75. 
Kemenkes RI. (2018). Data dan Informasi Profil Kesehatan Indonesia 2017. Pusat Data Dan Informasi Kementerian Kesehatan 2018.

Kementerian Kesehatan Republik Indonesia 2018. (2018). Info datin kesehatan RI 2018 Toss Tuberkulosis. 6. Retrieved from file:///C:/Users/User/Downloads/infodatin tuberkulosis 2018 (6).pdf

Kementrian Kesehatan Republik Indonesia. (2014). Pedoman Nasional Pengendalian Tuberkulosis.

Mando, N. J., Widodo, D., \& Sutriningsih, A. (2018). Hubungan Dukungan Keluarga Dengan Kepatuhan Minum Obat Pada Pasien TB Di Puskesmas Janti Kota Malang. Nursing News: Jurnal Ilmiah Keperawatan, 3(3), 550-556. Retrieved from https://publikasi.unitri.ac.id/index.php/fikes/article/view/1363

Maulidia, D. (2014). Hubungan Antara Dukungan Keluarga Dan Kepatuhan Minum Obat Pada Penderita Tuberkulosis Di Wilayah Ciputat Tahun 2014. Kepatuhan Minum Obat Pada Penderita Tuberkulosis.

Mongi, T. O., Rottie, J. V., \& Torar, A. (2017). HUBUNGAN DUKUNGAN KELUARGA DENGAN KEPATUHAN MINUM OBAT PASIEN TUBERCULOSIS DI RUANG IRINA C5 RSUP PROF.DR.R.D.KANDAOU MANADO. 5, 16-25.

Niven, N. (2012). Psikologi Kesehatan: Pengantar Untuk Perawat \& Profesional Kesehatah Lain. Jakarta: EGC.

Notoatmodjo, S. (2014). Ilmu Perilaku Kesehatan. Jakarta: PT. Rineka Cipta.

Pameswari, P., Halim, A., \& Yustika, L. (2016). Tingkat Kepatuhan Penggunaan Obat Pada Pasien Tuberkulosis Di Rumah Sakit Mayjen H. A. Thalib kabupaten Kerinci. Jurnal Sains Farmasi \& Klinis, 2(2), 116-121. Retrieved from http://jsfkonline.org/index.php/jsfk/article/view/60

Paradise, V. A. (2014). Hubungan Dukungan Keluarga Dengan Kepatuhan Minum Obat Pada Pasien Tuberculosis Paru Di Poli Paru Rumah Sakit dr. Saiful Anwar Malang.

Purnawan. (2008). Dukungan Suami Dan Keluarga. Jakarta: Salemba Medika.

Riskesdas. (2018). Laporan Nasional Riskesdas 2018.

Rosa, F. (2019). Hubungan Dukungan Keluarga Terhadap Kepatuhan Minum Obat pada Klien Tuberkulosis (OAT) Di UPT Puskesmas Teladan.

Rumimpunu, R. (2018). Hubungan Antara Dukungan Keluarga Dan Dorongan Petugas Kesehatan Dengan Kepatuhan Berobat Penderita Tuberkulosis Paru Di Puskesmas Likupang Kabupaten Minahasa Utara. Jurnal KESMAS, 7(4).

Saqib, S. E., Ahmad, M. M., \& Panezai, S. (2019). Care and social support from family and community in patients with pulmonary tuberculosis in Pakistan. Family Medicine and Community Health, 7(4), 1-9. https://doi.org/10.1136/fmch-2019000121

Sara, M. S. (2017). Hubungan Dukungan Keluarga Terhadap Kepatuhan Minum Obat pada Pasien TB Paru di Puskesmas Umbulhardjo 1 Yogyakarta. Studi, Program Keperawatan, Ilmu Kesehatan, Fakultas Ilmu.

Septia, A., Rahmalia, S., \& Sabrian, F. (2014). Hubungan Dukungan Keluarga dengan Kepatuhan Minum Obat pada Penderita Tb Paru. Jurnal Online Mahasiswa Program Studi Ilmu Keperawatan Universitas Riau, 1(2), 1-10. Retrieved from https://www.neliti.com/publications/185830/hubungan-dukungan-keluargadengan-kepatuhan-minum-obat-pada-penderita-tb-paru

Setiadi. (2008). Keperawatan Keluarga. Jakarta: Penerbit Buku Kedokteran EGC.

Setiati, at al. (2014). Buku Ajar Ilmu Penyakit Dalam. Jakarta: Interna Publishing. 
Sutanto. (2010). Cekal (Cegah Dan Tangkal) Penyakit Modern. Yogyakarta: Andi Offset.

Wianti, A. (2017). Hubungan Dukungan Keluarga Dengan Kepatuhan Minum Obat Pada Pasien Tuberculosis Paru Di Puskemas Kaladawa Kabupaten Tegal Tahun 2017. Jurnal Kampus STIKes YBIB Majalengka, VII(14), 1-14.

Xu, M., Markström, U., Lyu, J., \& Xu, L. (2017). Detection of low adherence in rural tuberculosis patients in china: Application of morisky medication adherence scale. International Journal of Environmental Research and Public Health, 14(3). https://doi.org/10.3390/ijerph14030248

Yuliana, F. (2019). Hubungan Dukungan Keluarga Dengan Kepatuhan Pengobatan Tuberculosis Paru Di Rumah Sakit Paru Dungus Madiun. 4(1), 66-70. 